Erratum

\title{
Proving paternity of children with deceased fathers
}

\section{Päivi Helminen ${ }^{1}$, Vivian Johnsson ${ }^{2}$, Christian Ehnholm ${ }^{2}$, and Leena Peltonen ${ }^{1}$}

${ }^{1}$ Laboratory of Molecular Genetics and ${ }^{2}$ Laboratory of Forensic Serology, National Health Institute, Mannerheimintie 166, SF-00300 Helsinki, Finland

Hum Genet (1991) 87:657-660

The Fig. 1a-c legend should be corrected in to the form: Samples: 1, grandfather; 2, child; 3 , grandmother; 4, mother. 